guides : Aristotle, Cuvier, von Baer and Johannes Mueller.

From 1921 to 1945 Russell was director of fishery investigations in the Ministry of Agriculture and Fisheries. As a fishery naturalist he had shown a talent for handling statistical material, conjuring biological and ecological discoveries from the records of quantities and sizes of fish on the fish-markets. Later, he decided to clarify the problem of the relation between the yield of a fishery and the vital processes that produce it : growth and reproduction, less mortality. Starting from first principles, he published, in 1931, "Some Theoretical Considerations . . .", and, as it transpired, ushered in a period of new understanding of this problem.

In the Conseil Permanent International pour l'Exploration de la Mer, Russell was an active officer ; and it was there that during 1930-35 he persuaded the European governments to embark on regulation of mesh of nets and size limits for fish in the overfished regions.

This was clearly a man of great and many-sided ability : a critic who shaped irreversibly the course of zoology and of fishery research ; a sensible and humane administrator ; fond of animals, naturalists and fishermen-he would always help any of them. $\mathrm{He}$ led a staff of scientists wisely, teaching us reliance on personality rather than in arrangements, and handing on his own sceptical appreciation that things are rarely what they seem. Would that there were more like him.

Michael Graham

\section{Dr. Jean White-Haney}

The death occurred in the United States on October 21, 1953, of Dr. Jean White-Haney, daughter of the late Mr. E. J. White, one-time assistant government astronomer in Melbourne. She was born in 1877, and after attending the Presbyterian Ladies College entered the University of Melbourne in 1901 to study biology, and graduated as B.Sc. in 1904 and M.Sc. in 1906. She was awarded a McBain Research Scholarship in the same year, and began research in the Botany Department under Prof. A. J. Ewart, at the same time taking University tutorials and teaching science at several schools, including her former one. She was also a University examiner at the public examinations. In 1908 she began full-time research under a grant from the Victorian Government. Between 1907 and 1911 thirteen papers bearing her name were published, eight papers on joint studies with Prof. Ewart and others on the flora of Australia, and also an appendix to his paper on longevity of seeds. In 1909 she was awarded a doctorate of science, being the second woman in Australia to receive this degree, for a thesis entitled "The Ferments and Latent Life of Resting Seed" which was published in the Proceedings of the Royal Society of London. Two papers on bitter pit in apples aroused great interest and controversy among horticulturists and staffs of State agricultural departments; the tentative view put forward by herself and Prof. Ewart, that bitter pit could be caused by arsenical spraying, was warmly debated. She was unable to complete the investigation, which was taken over by others under a joint arrangement between Federal and State Governments.

In 1912 she was appointed officer in charge of the Queensland Prickly Pear Board's research station in Dulacca, to initiate work towards eradication of this pest. In this she established the value of arsenical injections and sprays in killing the Dulacca prickly pear (Opuntia inermis) and of the wild cochineal insect in killing Opuntia monacantha, which was spreading in North Queensland and was afterwards eradicated by the insects. This work was recorded in four reports.

In 1916 she discontinued scientific work, having married Mr. Victor Haney in 1914. She continued to live in Queensland, and was member, and for a time secretary, of the Lyceum Club in Brisbane. In 1928, after further school teaching in Melbourne, she joined the staff of the Council for Scientific and Industrial Research as biological assistant and field officer. While in this position she wrote a history of Australian scientific work on the prickly pear. In 1929 she began a field investigation of the Noogoora burr (Xanthium pungens), which was a trouble in sheep pastures in New South Wales, and completed the basic taxonomic studies and survey of its distribution. In 1930 she joined her husband in the United States, and thereafter retired from active scientific work. Apart from one visit to Australia in 1936, she remained in that country until her death.

Dr. White-Haney is remembered by friends and former pupils for her genial personality and the enthusiasm she showed for anything she undertook, and which she succeeded in communicating to others. Several of those whose interest in biology she aroused at school, or at the university, have since made it their life's study. Even after her retirement she maintained an interest in science, and she regretted that the circumstances of her life prevented further active work, and also that she had to leave to others the completion of those investigations that she started.

R. C. Traill

\section{Prof. L. J. Stadler}

THE death occurred on May 11 of Lewis J. Stadler. Born at St. Louis on July 6, 1896, he received his B.S. degree at the University of Florida in 1917, and his doctorate from the University of Missouri in 1922. After working at Harvard as a National Research Fellow in biology, he became professor of field erops at the University of Missouri. At various times he occupied the position of visiting professor at the California Institute of Technology and that of senior geneticist and later principal geneticist to the Bureau of Plant Industry of the U.S. Department of Agriculture (1930-37).

Prof. Stadler was a member of the Botanical Society of America, the Genetics Society of America (of which he was president in 1938), the Americen Philosophical Society and the National Academy of Sciences.

His researches were principally in the field of induced mutations in plants, and his important contribution, "The Experimental Alteration of Heredity", published as Chapter 1 in "Science in Progress", Series II, contains the gist of his findings. His work has been of great significance for plant breeding, since the induction of mutations by the use of X-rays, ultra-violet light and other agents is now a valuable technique, which has been the means of effecting valuable improvements in agricultural plants. The American Scientist rightly says of him: "A great scientist with a friendly spirit has departed. He will long be remembered for his devotion to scientific research and especially its application to human needs". $\quad$ S. C. HARLAND 